\title{
Archives and the Labor of Building Feminist Theory: An Interview with Sharon Davenport
}

\author{
Vani Kannan
}

Vani Kannan is a an assistant professor of English at Lehman College, C.U.N.Y. She teaches composition/rhetoric, creative non-fiction and literature classes and co-directs Writing Across the Curriculum. Her writing grows out of women-of-color/transnational feminist histories and ongoing struggles.

\section{INTRODUCTION}

This article traces the labor of archiving the papers of the Third World Women's Alliance (TWWA), a women-of-color organization that grew out of the Civil Rights/Black Power movements and maintained active chapters in New York City and the Bay Area during the 1970s. I chose to research the TWWA and interview Sharon Davenport to get a sense of the labor of organizers, writers, and archivists that underlies the body of theory now known as US Third World/Intersectional Feminisms. The TWWA, along with countless other political organizations, built these theories through a range of compositions: political education documents, training materials, the newspaper Triple Jeopardy: Racism, Imperialism Sexism, and cultural work (encompassing songs, scripts, speeches, visual displays, food, childcare).

These compositions, along with the TWWA archives in their entirety, are now housed in the Sophia Smith Collection (SSC) at Smith College. Institutions of higher education in the United States have been both integral sites of Third World Liberation Movement-era activism (Hoang; Kynard) and leaders in empire building on political, economic, and cultural fronts (Chatterjee and Maira; Giroux). In that sense, these institutions mirror the US nation-state, which is both a global empire and the location of insurgent political organizing and activism. As Piya Chaterjee and Sunaina Maira write in their introduction to The Imperial University: Academic Repression and Scholarly Dissent, Dwight D. Eisenhower's famous "military-industrial-complex" speech originally referenced the "academic-military-industrial complex," pointing to the active role institutions of higher education have taken in weapons development and CIA/State Department ties - in other words, the forces the TWWA worked to counter. At the same time, the TWWA papers are some of the archive's most-used holdings and are used by educators and researchers across disciplines to unearth and reconstruct US Third World feminist-movement histories and put them into conversation with contemporary struggles.

None of this work would be possible without the labor of archiving the TWWA papers. Furthermore, through engaging with the process of archiving, we gain a deeper sense of why and how the archives came to be placed at Smith College. By focusing

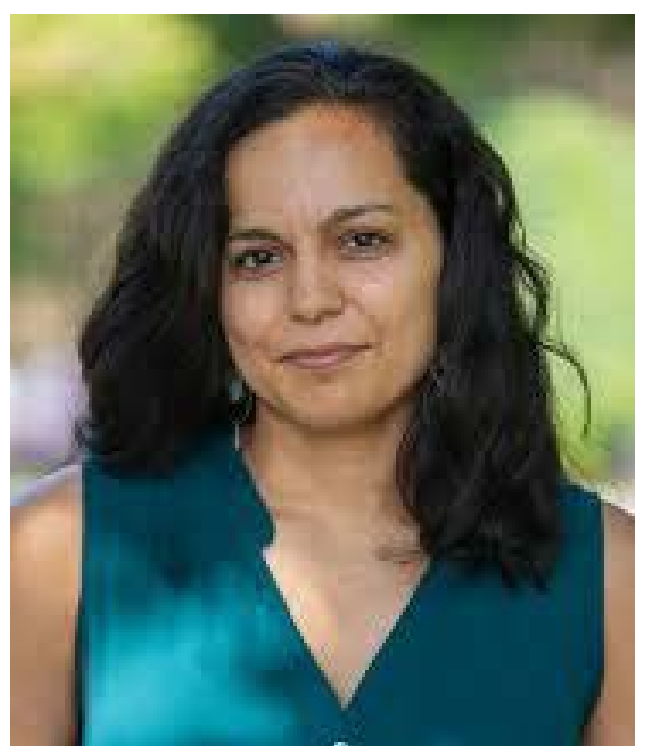

\section{Abstract}

This article traces the labor of archiving the papers of the Third World Women's Alliance (TWWA), a women-of-color organization that grew out of the Civil Rights/Black Power movements and maintained active chapters in NYC and the Bay Area during the 1970s. Drawing on an interview with Sharon Davenport, who processed the TWWA's archives, this article situates archiving as indispensable, feminized, and often-invisible labor that builds the context for feminist writing, theorizing, and teaching in institutions of higher education.

\section{Keywords}

archives, cultural work, feminist theory 
on the labor of archiving, I take my lead from the methodologies of social-movement scholars in rhetoric and writing who orient to the behind-the-scenes labor of organizing and the everyday textual labor of building movements and preserving movement histories (Leon; Monberg). My embodied experiences as a cross-disciplinary teacher/scholar of rhetoric and composition and women's and gender studies, and an organizer who prioritizes behind-the-scenes, gendered labor such as internal document preparation and childcare, orient me to the labor that scaffolds more public-facing work like publishing theory and public speaking. Drawing on an interview I conducted with Sharon Davenport, who processed the TWWA's archives, this article situates archiving as indispensable, feminized, and often-invisible labor that builds the context for feminist writing, theorizing, and teaching in institutions of higher education.

I was prompted to interview Davenport after chatting with a librarian at the Sophia Smith Collection and learning about Davenport's work on the archives. It struck me that despite years of doing archival research, I had never questioned who processed the archives I was working with or how they came to be housed in university libraries. Davenport's interview prompts us to ask important questions about the relationships among our identities, feminist histories, and the politics of archiving—questions central to the contexts in which we work and write.

\section{THE TWWA PAPERS}

As we consider the politics of archiving the papers of revolutionary movements, we see Davenport's orientation towards the archives is grounded in her longstanding work as a political activist and librarian. The labor of archiving movements begins years before an archivist's hands touch the materials for the first time; the orientation is built through years of work, organizing, and political study -in Davenport's case, as a political activist, archivist, and librarian. After attending Woodbury College and gaining some experience in archival work, she attended Smith College when she was in her 60s on a tuition scholarship and worked at the Sophia Smith Collection (SSC) for the three years she attended Smith. She was also a founding member of the Brick Hut Cafe, a worker-owned LGBT community fixture in the Bay Area (Davenport, "LGBT Pride"), and is a member of the Bay Area Lesbian Archives.

While she had grown up in the Bay area and attended the TWWA's International Women's Day cultural events there, she was not familiar with the group's other work because of the lack of published material on it. In 2004, she received a Praxis Grant from Smith to travel to Oakland, California, where she connected with Linda Burnham, one of the TWWA's founding members who was then executive director of the Women of Color Resource Center. ${ }^{1}$ Burnham asked Davenport to process the TWWA papers for the duration of her grant. Working in collaboration with Burnham, in conversation with her faculty mentor at Smith, and doing quite a bit of independent research, ${ }^{2}$ Davenport finished her 220 hours and stayed on even longer to finish processing "boxes and boxes and boxes and boxes of disorganized papers, pamphlets, posters, all kinds of stuff."

Processing the papers filled in the historical gaps for Davenport. She had been deeply influenced by Frances Beal's "Double Jeopardy: To Be Black and Female" (Davenport, "Francis Beal's"), along with the writings of Angela Davis, Sara Evans, Kimberly Springer, and The Black Woman collection writers. Processing the archives allowed her to see the theories of these writers in concrete, everyday practice through grassroots organizing, political education, newspaper publication, cultural work, and coalitional work with other radical Third World organizations. Davenport describes the archiving process as "mind altering," "revelatory," "life-changing work" that gave her a glimpse into the TWWA's "centrality to the development of the women's-liberation movement." This prompted her to question the dominant periodization of the feminist movement in the United States and the invisibility of revolutionary women-of-color organizing work:

This project began with stacks of disorganized storage boxes overflowing with a variety of documents and photographs spanning over ten years of organizational activism. I processed these papers from material chaos-identifying conservation and preservation issues as I organized-to finding aid [an inventory of archival materials]. In the process of organizing these documents, I was able to map the social and organizational history of the Third World Women's Alliance from group statements, publications, meeting notes, correspondence, and ephemera of the TWWA's members. These important records of a foundational African American, Asian American, and Puerto Rican activist, womanist organization are now safely housed and research-ready collections. My experience of organizing the TWWA's documentation of a revolutionary, women-of-color, mass organization led me to reinvestigate the historiography of black feminist movements in the US.

Davenport described being "blown away" by every piece of paper she encountered and expressed profound respect for the depth with which the organization engaged its theoretical and political questions:

They went deep. They weren't going for broad; they were going deep. They were questioning, they were self-criticizing,

\footnotetext{
1 The TWWA became the Alliance Against Women's Oppression, and then the Women of Color Resource Center, which operated until 2011 ("Sharing Sorrow").

2 Not much had been published on the TWWA at this point, but Kimberly Springer's book Living for the Revolution proved useful to Davenport.
} 
they were putting out white papers . . . their papers that expressed the belief that ordinary women could become leaders. Wow! What a concept. They believed in collective support of women of color to make change.

As she made her way through the papers, Davenport gained insight into the TWWA's intervention in the white, middle-class women's movements of the 1970s:

Basically, and I don't mean this derogatorily, the white women's liberation movement was basically middle-class women ... very few working-class women were involved in the initial organizing. But really, the TWWA and other Black feminisms really pushed them hard, challenged them hard, to get a line on anti-imperialism and antiracism, and anti-institutional racism in the United States. So, it was a revelation to me, what these women were doing.

In addition to archiving and categorizing these boxes of materials, Davenport created a finding aid to make the categorized papers easily accessible. Reflecting on her time processing the archives, Davenport expressed deep appreciation to Linda Burnham for the opportunity and support in this work. Reflecting on Davenport's work, Linda Burnham expressed a deep appreciation as well, explaining how Davenport's work offered an opportunity for former TWWA members to collect their materials and think through how they wanted these materials to be used:

Sharon has worked incredibly hard to bring organization to the chaos of the Third World Women's Alliance papers and materials. We had boxes of stuff from multiple individuals in no particular order ... the fact that she was here doing the work provided the extra incentive for TWWA member[s] who had not turned over their papers to do so. Sharon's work has made it possible for us both to know what we have and to know what's missing that we might want to seek out. Further, she has created the basis for former TWWA members to take up the conversation about where we want to store our papers so that researchers will have access to them.

In other words, the process of archiving can support practices of reflection and assessment of social movements. Davenport wanted to make sure the archives were placed in a repository where they would be made available for use. Because of her familiarity with the SSC from her experience as a student at Smith, and her familiarity with several other archives that had large backlogs of unprocessed material, Davenport advocated that the TWWA archives be placed at the SSC. This desire to make archival materials accessible to the public brings up a contradiction Davenport points out: grassroots community archives do not always have the resources to process archival materials quickly and might have large backlogs.
During this time, the SSC, in collaboration with activist and professor Loretta Ross, was actively trying to reflect more histories of women-of-color political activism. The Voices of Feminism Oral History Project, along with archives like the TWWA's, played a central role in pushing the archives in this direction. To transform the archive, a team of archivists collected over fifty oral histories through the Voices of Feminism Oral History Project, which "documents the persistence and diversity of organizing for women in the United States in the latter half of the 20th century" ("Introduction"). Ultimately, SSC received the TWWA papers because Davenport knew they had the resources to make them available for public use $^{3}$ and treat them "with respect." Upon receiving the papers, archivists at SSC rewrote the finding aid and introduction; because Davenport had processed the archives to Smith's specifications, the "very tedious but honorable work" of processing the archives was not changed. Thus, the archives were made available for use very quickly. Davenport was particularly happy that, at SSC, the archives would be used "by mostly young women whose education in [the TWWA's] iterations of feminism, Black feminism, must be eye-opening to them."

Triple Jeopardy has become the most popular element of the TWWA papers. Accessioning archivist Kathleen Nutter has used Triple Jeopardy as a resource to help researchers studying the different groups that worked with the TWWA, including the Black Panther Party. The newspaper has served her well as a summary of other movements and alliances of the era. For example, in an interview with me, she recalled a phone call from a California-based graduate student writing a dissertation on Black-Palestinian solidarities who asked whether Triple Jeopardy had covered these relationships. Nutter flipped through the archived issues of the newspaper, and "lo and behold, I found 8 to 9 articles, full-page spreads, on what was happening in Palestine, how to support the PLF and the Black community . . . you can find anything in Triple Jeopardy! It's a fabulous resource that gets used in so many classes." The TWWA's newspaper thus serves as an important historical record of Third World Liberation movement-era collaborations and solidarities. As Nutter put it, "Of the TWWA archives, [Triple Jeopardy] is the go-to because it's so visual. It really draws people in." People travel from all over the world, and drive hundreds of miles, to work with Triple Jeopardy.

\section{ARCHIVAL CONTEXTS FOR THEORY MAKING AND PEDAGOGY MAKING}

The work detailed above forms at least part of the context from which we should understand any meaning writers/organizers/ students/scholars make from the Alliance's archives. Asking critical questions about the labor underlying feminist theory making requires thinking about both the context of Smith College and the academy as a context in which terms like

3 The SSC does not require affiliation with an educational institution in order to access the archives. 
intersectionality-instantiated in organizing by groups like the Alliance-come to structure scholarship and teaching. While Smith is an expensive elite school with a predominantly white student body ${ }^{4}$ (contrary to the TWWA's multiracial, anticapitalist ethos), the multivalent uses of the TWWA archives demonstrate that just as the east/west and first/third world lines are blurry and co-constitutive, campus/community and academic/organizing binaries are as well.

Part of navigating this liminal space is deconstructing how words like intersectionality come to be taken up and often abstracted from their roots in organizing work like the TWWA's. This is the precise reason many professors teach with the TWWA archives: to reground intersectionality in the everyday organizing labor of women of color responding to urgent exigencies like forced sterilizations ${ }^{5}$ and workplace exploitation. In her oral history, TWWA organizer Linda Burnham situates the group as intersectional in its analysis, regardless of whether it used the term:

[S]ome of this [analysis is what] later came to be called intersectionality, which is a very complicated term, but the ideas behind that were formed in these early years, where people were essentially saying: We're whole people, and we can't combat women's issues as though we're unaffected by issues of race, as though we're unaffected by the issues that face our broader communities. So the Third World Women's Alliance was an early -it's not the only-but was an early articulation of this. (20)

Davenport also pointed to the TWWA's grounding in the lived experience of intersecting oppressions and highlighted how the TWWA pushed for a more intersectional understanding of women's liberation:

Intersectionality and intersections get tossed around quite a bit, but we owe this idea, this concept, we owe it absolutely to Black women feminists. There is no doubt in my mind that that concept comes out of their triple oppressions. I think Shirley Chisholm said, "When I walk out the door in the morning, I know that I'm black, and a woman, and living in an imperialist society." . . . The TWWA and other Black feminisms really pushed [the women's liberation movement] hard, challenged them hard, to get a line on anti-imperialism and antiracism and anti-institutional racism in the United States.

Davenport emphasized the class analysis and Marxist-Leninist theoretical influence of the TWWA as well, with appreciation for how the group developed leadership out of the lived experience of oppression rather than relying on educational/other professional qualifications for leadership.

Such a theory of leadership is directly tied to methods for organizing spaces, which are visible in the group's archived documents. For Davenport, these documents offer crucial insights for organizing today, particularly in terms of engaging political questions deeply through sustained debate and discussion that centers the voices of working-class women of color. For her, the TWWA is "a model" for grassroots organizing, in part because of how the group developed analyses and actions out of the lived experiences of its membership. Davenport pointed to the group's policy of engaging in criticism/self-criticism and carefully documenting its limitations and self-critiques, ${ }^{6}$ which has influenced the way she engages in organizing work today:

I belong to an organization right now called the Bay Area Lesbian Archives. ... My influence from the TWWA informs how I respond within this group of people about racism, anti-imperialism, and all of these things. . . And so, we talk in depth; we do criticism/self-criticism; [it's a] very important thing, to criticize yourself and others, admit when you're wrong, and talk about it. ... I think that the depth with which the TWWA looked at itself constantly-what could we have done better?-is so important to groups now trying to establish themselves as anti-imperialist, antiracist.

In relation to this type of internal organizational work, Davenport and I were both drawn to the intentionality of the TWWA's political education work. For example, TWWA members did not assume prior understanding of or consensus on the definition of terms like imperialism but worked to build definitions together. Davenport summarized these lessons by emphasizing the need for slow, patient political education and discussion that engages all group members and is attentive to raced/gendered dynamics:

Take that time. Go deep. Everything's important. Every one is important. Everyone should have a voice. That caution to allow working class women and women of color to speak first and to give them room to talk is monumental, I think. I really do.

And now, when I'm in groups, and I see white women with good intentions-because maybe they do know something important, and maybe they do have the education or the privilege, really, of knowing some things that are important to the discussion-should allow working-class women

4 According to Collegedata.com, Smith College is $52.9 \%$ white ("College Profile").

5 Recent reports of ICE's forced sterilizations make these materials excellent pedagogical materials—along with texts like the film La Operación-for teaching students about structural racism in reproductive health care.

6 When the WCRC closed, a thirty-plus-page critical reflection titled "Sharing Sorrow: Women of Color Resource Center's Downfall" was produced and published; Davenport links this to the TWWA's practice of criticism/self-criticism. 
and women of color to speak, and to have their piece said because they often feel, I think, although less and less I hope ... feel like they have nothing to say because they feel maybe I don't have the education, or maybe I don't have the experience. But they have their own experience and they are educated. Everyone in our culture is educated to the ways in which power corrupts and power holds the reins of so many of the goodies-ha!-the necessities of life. Food clothing shelter. And that they keep that close to them, they hoard it.

Who am I speaking of? Well there's a phrase now, the $1 \%$ but power. Power. Political power. And financial power to control the lives of people. If you're just struggling every day to survive, that's a revolutionary act at this point, and always has been. And that's another piece from out of the TWWA is that just surviving is a revolutionary act if you're a person of color in this country. Survival, wow. That's not only sad, but for me it produces a kind of anger that people are treated in a way that doesn't allow them to act in their own best interest.

Davenport's words encourage us to see Third World/intersectional feminist theories not as resources to be hoarded but as processes that engage people in identifying their embodied knowledges and articulating their rage at unjust systems. She connects this political depth and slow deliberate work of movement building to the patience required of an archivist. Drawing connections between the work of organizing and the work of archiving, she encourages us to think about the deep affinities between these labors:

[The TWWA is] a model to me of how to organize at a grassroots level as well as at other levels. Yeah, but beginning with the grassroots, beginning with that. Building from-1 don't want to call it the bottom-but building from a baseline, you know? Like, what's wrong with this picture? And then ask yourself, why is this so? How has your mind been colonized? But you have to ask those questions-you have to. And that's what I mean by going deep. I mean, maybe you get some of it wrong, but you get some things right. And then you go on, and try to figure it out. You have to have patience. As an archivist, l'll tell you, you have to be patient to archive things! It takes a great deal of patience, sitting and thinking and looking and paying attention to every single thing. Yes, you have to do that. Otherwise, we'll get nowhere, you know?

Here, Davenport crystallizes an approach to social-movement archiving that mirrors the painstaking work of consciousness-raising and organizing - one that foregrounds patience and a critique of colonial epistemologies. Given the painstaking and patient nature of this work, how does this approach translate into pedagogy and the time/resources necessary to circulate the archives beyond Smith College? Professors who teach with the TWWA archives have developed pedagogical strategies for engaging social-movement exigencies in their work and doing research organizers do not always have time or support to do. For example, professor Jennifer Guglielmo's students have used archival materials, including the TWWA's, to build digital timeline training materials for a domestic worker-led organization that wants members to understand themselves as part of a long lineage of social-movement organizing. The students respond directly to the organizers' asks and engage in collaborative digital compositions that then become on-the-ground training materials. These concrete connections offer ways of thinking about archives as a site of interdisciplinary, public pedagogies that take a lead from the slow work of both movement- and archive building.

\section{EMBODIED REFLECTIONS, LESSONS, AND ONGOING QUESTIONS}

As I engaged in these questions with Davenport, we were both prompted to reflect on how our identities and lived experiences shape our understandings of archival work and its politics. Davenport and I are both non-Black women of color who were drawn to radical Black feminist politics. Indeed, I encountered the Alliance for the first time in Dr. Gwendolyn Pough's Black Feminist Theories course when we read founding member Frances Beal's "Double Jeopardy: To Be Black and Female." Davenport and I share an understanding that our own "ins" to women-of-color feminisms and organizing are indebted to Black feminisms. This understanding impacts the way we each understand our own identities while doing this work-we understand our own politics as always oriented to the interventions of radical Black feminisms and womanisms.

Davenport and I are both from mixed Asian families (her, Filipina/ Scottish; me, Indian/Irish/Italian), and together we reflected on the fact that the TWWA is an important reference point to counter ongoing depictions of Asian Americans as model minorities. Professors at Smith note that histories like the TWWA's help students of color see themselves as historical actors and part of a long line of communities of struggle; this was also the case for the two of us. The model minority trope not only serves to divide would-be multiracial coalitions, it erases insurgent Asian American struggles. As Davenport put it, "Asian Americans have been speaking truth to power since the immigration of Chinese and Japanese and South Asian people into the United States for work, primarily. And so there have been many many Asian American revolts against this system of oppression that left them working for a bowl of rice." Davenport was also struck by the archival evidence of the TWWA's involvement in the United Farm Workers struggle, for example, their work to help build the Agbayani retirement village for elderly 
farm workers. ${ }^{7}$ Davenport connected it to her father's experience as a seasonal farm worker, demonstrating the power of learning history that writes your body into histories of struggle. For me, researching the TWWA led me to reflect on the lack of involvement of South Asian women in the group-a gap that now animates my research on the racialization of South Asians in the United States in relation to women-of-color feminist politics.

Through discussing these connections, Davenport and I drew connections to the strange experience of encountering the TWWA history in institutions of higher education and their class-mobility imperative set alongside the "class-suicide" imperative of antiimperialist social movements (to quote Amilcar Cabral). On this topic, Davenport connected the TWWA's white paper on "careerism" to her work with the Brick Hut Cafe. She noted that she and another working-class woman were the only two people left at the end of the cafe's life because others left to pursue careers and middle-class lives:

[The TWWA's white paper on careerism] spoke to me of how because of the necessity of earning a living, women often chose to leave revolutionary groups because they weren't making any money, or enough money to maybe have a lifestyle that they were seeking. At any rate, this was called careerism. So they quit groups that were making a difference in the street, for women of color, in order to go and get a degree or maybe change directions and seek a career. So you have to ask yourself, who has time to devote to revolution? Are you willing to give up all of the luxuries of a middle-class life in order to further the revolution?

Davenport's final question asks those of us who work full time in institutions of higher education to critically interrogate the limitations of our work there but also to orient to the insurgent social-movement histories that animate higher education-histories that crossed over into the TWWA's. Members of the TWWA were active in the Third World Liberation Strike at San Francisco State University and the CUNY student strike. The TWWA archives show many moments of crossing over into campus spaces for meetings and events, and members taught ethnic studies courses. ${ }^{8}$ Without Davenport's labor, these examples of the "porous borders" ("An Interview") of what is often consolidated as "campus" and "community" would be hidden.

For me, one of the central lessons of this archival project is to honor the TWWA's many methods of theory- and movement building, alongside the often-invisible, "tedious but honorable" work of archiving these histories. I share Davenport's words as a call to those of us who study the craft and context of writing to make visible the labors that build our contexts for writing, theorizing, and pedagogy making.

\section{Works Cited}

"Agbayani Work Brigade, United Farm Workers." 1973-74. Box 5, Folder 4. Third World Women's Alliance Papers. Sophia Smith Collection, Smith College Libraries, Northampton, MA. Accessed 16 August 2016.

Burnham, Linda. "Oral History." Interview by Loretta J. Ross. Smith College Libraries, Voices of Feminism Oral History Project, 18 March 2005. Web. Collegedata. Accessed 1 June 2017. https://www.smith.edu/libraries/libs/ssc/vof/ transcripts/Burnham.pdf

Cabral, Amilcar. "The Weapon of Theory." 1966. https://www. marxists.org/subject/africa/cabral/1966/weapon-theory.htm

Chatterjee, Piya, and Sunaina Maira, eds. The Imperial University: Academic Repression and Scholarly Dissent. University of Minnesota Press, 2014.

"College Profile: Smith College." College Data, 2016. Web. Accessed 12 November 2017.

Davenport, Sharon. "Frances Beal's 'Double Jeopardy' Theory and Practice." Personal Correspondence.

Davenport, Sharon. "LGBT Pride: Remembering the Brick Hut Cafe-Part 1." Bay Area Bites, 23 June 2011. Web. Accessed 11 November 2017.

Davenport, Sharon. Personal interview. 5 August 2017.

"Dear Sisters." 8 September 1976. Box 1, Folder 2. Third World Women's Alliance Papers. Sophia Smith Collection, Smith College Libraries, Northampton, MA. Accessed 14 April 2017.

Giroux, Henry A. The University in Chains: Confronting the Military-Industrial-Academic Complex. Routledge, 2007.

Hoang, Haivan. Writing against Racial Injury: The Politics of Asian American Student Rhetoric. University of Pittsburgh Press, 2015.

"Introduction." Smith College Libraries, Voices of Feminism Oral History Project, 2017. Web. Accessed 4 September 2017.

Kynard, Carmen. Vernacular Insurrections: Race, Black Protest, and the New Century in Composition-Literacies Studies. State University of New York Press, 2013.

Leon, Kendall. "La Hermandad and Chicanas Organizing: The Community Rhetoric of the Comición Femenil Mexicana Nacional Organization." Community Literacy Journal, vol. 7, no. 2, 2013.

"An Interview with Chandra Talpade Mohanty" (with Vani Kannan and Karrieann Soto Vega). This Rhetorical Life. Podcast. Forthcoming, 2020. Web.

Monberg, Terese. "Listening for Legacies, or How I Began to Hear Dorothy Laigo Cordova, the Pinay behind the Podium Known as FAHNS." In Representations: Doing Asian American Rhetoric, edited by LuMing Mao and Morris Young. Utah State University Press, 2008, pp. 83105.

7 See "Agbayani Work Brigade, United Farm Workers" for information on the TWWA's involvement.

8 See "Dear Sisters" regarding an evaluation meeting that would take place October 16, 1976, at the Women's Center Lounge at UC Berkeley. 
"National Report - LESLIE \& TONI'S PARTICIPATION." 1973-

75. Box 4, Folder 1. Third World Women's Alliance

Papers. Sophia Smith Collection, Smith College Libraries,

Northampton, MA. Accessed 5 May 2017.

Nutter, Kathleen. Personal interview. 12 June 2017.

"Sharing Sorrow: Women of Color Resource Center's Downfall."

Community Taskforce, March 2011. Web. Accessed 11

November 2017.

Springer, Kimberly. Living for the Revolution: Black Feminist

Organizations, 1968-1980. Duke University Press, 2005. 